\title{
Astrocyte-Produced Ephrins Inhibit Schwann Cell Migration via VAV2 Signaling
}

\author{
Fardad T. Afshari, Jessica C. Kwok, and James W. Fawcett \\ Cambridge Centre for Brain Repair, Department of Clinical Neurosciences, University of Cambridge, Cambridge, CB2 OPY, United Kingdom
}

Schwann cells are a promising candidate for bridging spinal cord injuries and remyelinating axons. However, grafted Schwann cells show little intermingling with host astrocytes and therefore limited migration from transplant sites. This leads to the formation of a sharp border between host astrocytes and Schwann cells, which results in axons stalling at the graft-host interface and failing to exit the graft. We investigated the possibility that Eph/ephrin interactions are involved in the segregation of Schwann cells and astrocytes and in limiting Schwann cell migration. Using reverse transcription-PCR, we have characterized the ephrin and Eph profile in cultured Schwann cells and astrocytes, showing that astrocytes produce all the ephrinAs and Schwann cells produce the receptors EphA2, EphA4, and EphA7. Several ephrinAs inhibit Schwann cell migration on laminin, with ephrinA5 being the most effective. Blocking the EphA receptors with excess EphA4-Fc increases Schwann cell migration on astrocytes and improves Schwann-astrocyte intermingling. We show that the action of ephrinA5 on Schwann cells is mediated via VAV2. Both clustered ephrinA5 and astrocyte contact increases the phosphorylation of VAV2 in Schwann cells. Knockdown of VAV2 abrogates the inhibitory effect of clustered ephrinA5 on migration and increases the ability of Schwann cells to migrate on astrocytes. In addition, we found a role for ephrinA5 in inhibiting Schwann cell integrin signaling and function. Overall, we suggest that Eph/ephrin interactions inhibit Schwann cell migration and intermingling with astrocytes via VAV signaling affecting integrin function.

\section{Introduction}

Schwann cells transplanted into the CNS can promote the regeneration of CNS axons and replace lost myelin (Takami et al., 2002; Pearse et al., 2007). They can be expanded in vitro from nerve explants or skin-derived stem cells and are therefore potentially useful as autografts for spinal cord repair and peripheral nerve bridges (Morrissey et al., 1991; Casella et al., 1996; Guest et al., 1997; Bunge and Pearse, 2003; Biernaskie et al., 2007; Bunge, 2008). Although many studies have demonstrated the potential of Schwann cells for these applications, some problems have to be addressed to make them useful (Dam-Hieu et al., 2002; Takami et al., 2002; Biernaskie et al., 2007; Pearse et al., 2007; Tabesh et al., 2009).

One of the main problems is that the cells show very limited migration from the site of implantation and do not intermingle with host astrocytes (Sims and Gilmore, 1994; Sims et al., 1998; Fraher, 1999; Lakatos et al., 2000; Andrews and Stelzner, 2007). Interfaces between Schwann cell and astrocyte territory are characterized by a sharp boundary of reactive astrocytes expressing, among other molecules, inhibitory chondroitin sulfate proteo-

Received July 13, 2009; revised Nov. 16, 2009; accepted Dec. 8, 2009.

This work was funded by grants from the Medical Research Council, the Henry Smith Charity, the John and Lucille van Geest Foundation, the European Union Framework 6 Network of Excellence NeuroNE, and the European Union Framework 7 Programmes Spinal Cord Repair and Angioscaff. We thank Drs. Caroline Brenan and Steve Bolsover for their gift of PCR primers for Ephrins and Ephs and Dr. David Wilkinson for his gift of EphA4 antibody and for his advice. We thank Dr. Elske Franssen and David Story for their assistance and discussions.

Correspondence should be addressed to James W. Fawcett, Centre for Brain Repair, University of Cambridge, Robinson Way, Cambridge, CB2 OPY, UK. E-mail: jf108@cam.ac.uk.

DOI:10.1523/JNEUROSCI.3351-09.2010

Copyright $\odot 2010$ the authors $\quad 0270-6474 / 10 / 304246-10 \$ 15.00 / 0$ glycans (CSPGs) (Geller and Fawcett, 2002; Silver and Miller, 2004). Although many axons cross this inhibitory boundary to enter the Schwann cell grafts, few axons leave the attractive Schwann cell environment back into the CNS territory to make connections with host neurons (Richardson et al., 1982; Adcock et al., 2004; Li et al., 2005). Similarly, coculture of Schwann cells and astrocytes shows separate territories with sharp boundaries between them (Ghirnikar and Eng, 1995; Wilby et al., 1999; Lakatos et al., 2000). Addition of neurons on these cultures shows that their axons grow preferentially on the Schwann cells and seldom leave the Schwann cell environment to grow on astrocytes (Adcock et al., 2004).

The molecular interactions involved in the segregation of Schwann cells and astrocytes and in the inhibition of Schwann cell migration in astrocyte territories are only partially understood. One candidate is Eph/ephrin-mediated cell repulsion. Eph/ephrin interactions lead to the segregation and sorting of various cell types, formation of rhombomere boundaries, guidance of neural crest migration, and repulsion of growth cones (Krull et al., 1997; Monschau et al., 1997; Robinson et al., 1997; Smith et al., 1997; Gao et al., 1998; Mellitzer et al., 1999; Kullander et al., 2001; Xu et al., 1995, 2000). EphrinB2 on reactive astrocytes and EphB2 on fibroblastic meningeal cells are involved in the formation of the astrocyte-meningeal boundary (Bundesen et al., 2003). An important route of Eph signaling is via the VAV guanidine nucleotide exchange factor (GEF) family, which modulates the activity of Rho, Rac, and Cdc42 (Hornstein et al., 2004).

In this study, we investigate the expression profile of Ephs and ephrins on Schwann cells. We demonstrate that Schwann cell migration is inhibited by ephrinAs and that blocking astrocyte- 
produced ephrinAs allows Schwann cell-astrocyte mixing. We further show that ephrin signaling involves the VAV pathway and influences integrin-mediated Schwann cell migration.

\section{Materials and Methods}

Antibodies and reagents. Antibodies used were as follows: mouse monoclonal anti-rat p75 (1:1000; Millipore Bioscience Research Reagents), rabbit polyclonal anti-GFAP (1:500; Dako), chicken polyclonal antiGFAP (1:2000; Abcam), rabbit polyclonal phospho-VAV2 (pVAV2) tyr172 (1:1000; ECM Biosciences), rabbit monoclonal anti-VAV2 (1: 1000; Abcam), rabbit polyclonal anti-phospho-focal adhesion kinase (FAK) tyr397 (1:100; Invitrogen), rabbit polyclonal anti-S100 (1:500; Dako), rabbit anti-EphA4 (1:1000; generous gift from Dr. Wilkinson, Medical Research Council, London, UK), mouse monoclonal antiEphA2 (1:1000; Millipore Corporation), hamster anti-rat $\beta 1$ blocking antibody (1:200; BD Pharmingen), hamster anti- $\beta 3$ blocking antibody (1:200; BD Pharmingen), rabbit polyclonal anti-FAK (1:100; Biosources), anti-mouse/rat CD29-FITC-conjugated antibody (1:200; Biolegends), mouse polyclonal anti-ephrinA5 (1:1000; Abcam), rabbit polyclonal anti-ephrinA5 (1:1000; Abcam), and mouse monoclonal antiEphA7 (1:500; Abcam). Alexa fluor-conjugated secondary antibodies were all obtained from Invitrogen and used at 1:500 dilutions. Ephrins and Eph-Fc were purchased from R \& D Systems (used at $10 \mu \mathrm{g} / \mathrm{ml}$ ). Goat anti-human secondary antibody (Jackson ImmunoResearch) was used for clustering ephrin-Fc in 1:10 ratio.

$\mathrm{MnCl}_{2} \cdot 4 \mathrm{H}_{2} \mathrm{O}$ (Sigma) was used at $500 \mu \mathrm{M}$, and laminin (Sigma) was used at $1 \mu \mathrm{g} / \mathrm{ml}$.

DMEM, HBSS, and fetal calf serum (FCS) were all purchased from Invitrogen. Penicillin-streptomycin-fungizone (Sigma) was used at $1 \%$.

Schwann cell cultures. Schwann cells were prepared from postnatal day 1-3 Sprague Dawley rat sciatic nerves, using a variation of a procedure described previously (Brockes et al., 1979). Sciatic nerves were cleared of their epineurium and then incubated in collagenase $(0.03 \%$; Sigma) for $15 \mathrm{~min}$, followed by trypsin ( $0.1 \%$; Sigma) for $15 \mathrm{~min}$. Triturating solution [containing $300 \mathrm{mg}$ of BSA (Sigma), $1 \mathrm{mg}$ of DNase (Sigma), and 50 $\mathrm{mg}$ of trypsin inhibitor (Sigma) per $100 \mathrm{ml} \mathrm{HBSS}$ ] was added, and the nerves were triturated. Centrifuged cells were resuspended in DMEM/ $10 \%$ FCS on laminin ( $1 \mu \mathrm{g} / \mathrm{ml}$; Sigma) or poly-D-lysine (PDL) $(20 \mu \mathrm{g} / \mathrm{ml}$; Sigma) coated flasks. From day 2 , cytosine arabinoside $\left(1 \times 10^{-5} \mathrm{M}\right.$; Sigma) was added for $2 \mathrm{~d}$, followed by $2 \mathrm{~d}$ in DMEM $/ 10 \%$ FCS, repeated twice. Remaining fibroblasts were removed using complement lysis with anti-Thyl.1 antibody (1:5 hybridoma cell supernatant T11D7) and rabbit complement (1:5; Serotec). Schwann cells were then proliferated in DMEM, 10\% FCS, $2 \mu \mathrm{M}$ forskolin (Calbiochem), and bovine pituitary extract (BPE) $(10 \mu \mathrm{g} / \mathrm{ml}$; Sigma).

Astrocyte cultures. Astrocyte culture technique was adapted from McCarthy and de Vellis (1980).

Cortices of neonatal day 1-3 Sprague Dawley rat pups were demembranated, chopped, incubated with $0.1 \%$ trypsin for $30 \mathrm{~min}$, triturated in triturating solution, resuspended in DMEM/10\% FCS, and plated in PDL-coated 75 cc flasks. After 7-10 d, microglia and oligodendrocyte precursor cells were removed from the astrocytes by shaking for $15 \mathrm{~h}$ at 50 rpm at $37^{\circ} \mathrm{C}$ (Luckham R300).

Migration assay. The inverted coverslip assay is a variation of that first described previously (Fok-Seang et al., 1995; Wilby et al., 1999). Coverslip fragments were coated with PDL, and then an equal number of Schwann cells in $20 \mu \mathrm{l}$ drops were placed on each coverslip fragment. After $2 \mathrm{~h}$, medium was added to cover the fragments. The cells were incubated in Schwann cell medium containing BPE (10 $\mu \mathrm{g} / \mathrm{ml}$; Sigma) and forskolin ( $2 \mu \mathrm{M}$; Calbiochem) for $24 \mathrm{~h}$. The coverslip fragments were inverted face down on to the test surface after repeated dipping to remove poorly attached cells. Cells were allowed to migrate for $24-48 \mathrm{~h}$, fixed in $4 \%$ paraformaldehyde, and stained for $\mathrm{p} 75$. The maximum distance of migration and the number of cells migrating at each distance was measured. Each data point is the mean of at least three coverslips, repeated at least three times using independent cell batches.

In experiments involving ephrins, soluble ephrins-Fc ( $\&$ \& D Systems) were preclustered with goat anti-human secondary antibody (Jackson
ImmunoResearch) at 1:10 for $1 \mathrm{~h}$ at room temperature. The preclustered ephrins were applied to cultures at $10 \mu \mathrm{g} / \mathrm{ml}$.

Boundary assay. A $50 \mu \mathrm{l}$ droplet of Schwann cell suspension $\left(2 \times 10^{6}\right.$ cells $/ \mathrm{ml}$ ) was placed at one end of a PDL-coated chamber slide well (Nalge Nunc International), and a glass strip was used to smear the drop toward the center of the chamber to generate a straight edge. A second 50 $\mu l$ drop containing astrocytes was placed at the opposite end of the well and smeared to give a straight edge parallel to and $0.2 \mathrm{~mm}$ from the first. After $2 \mathrm{~h}$, cultures were washed to remove non-attached cells and then grown for $10 \mathrm{~d}$ in DMEM supplemented with BPE/forskolin. In experiments involving EphA4-Fc, the medium was changed to DMEM supplemented with $10 \%$ FCS before the start of the experiment. EphA4 (10 $\mu \mathrm{g} / \mathrm{ml}$; R \& D Systems) was added to the medium every $24 \mathrm{~h}$ for $3 \mathrm{~d}$. For quantification. a line was drawn at the front edge of astrocyte territory, and then the number of Schwann cells migrating into astrocyte territory was counted at distances of 100, 200, and $>200 \mu \mathrm{m}$. Experiments were repeated at least three times with independent cell batches.

Immunocytochemistry. Cells were fixed for $15 \mathrm{~min}$ in $4 \%$ paraformaldehyde, washed, and blocked in $0.2 \%$ Triton- $\mathrm{X}$ and $10 \%$ goat serum for 40 min. Primary antibody (see above) with $10 \%$ goat serum was incubated overnight. The cells were then washed and incubated with secondary antibody for $1 \mathrm{~h}$. The excess secondary antibody was then removed by three washes. The coverslips were then mounted onto slides using fluorosave. For experiments looking at the surface level of integrins, no Triton-X was used. For DAB staining, biotinylated secondary antibodies were used: anti-mouse (1:200; Vector Laboratories) or anti-rabbit (1: 200; Vector Laboratories) for $1 \mathrm{~h}$. This was followed by washes and subsequent addition of streptavidin $\mathrm{ABC}$ Elite kit (Vector Laboratories) for $1 \mathrm{~h}$ and then DAB (Sigma). For live staining, primary antibodies were added to the medium for $15 \mathrm{~min}$, followed by three washes using PBS. The secondary antibodies were then incubated with cells for an additional $15 \mathrm{~min}$. The cells were then washed and fixed using ice-cold methanol for $3 \mathrm{~min}$.

Reverse transcriptase-PCR. RNA was extracted from purified primary sciatic nerve Schwann cells and primary cortical astrocytes derived from postnatal days 1-3 Sprague Dawley rats. For positive controls for Eph and ephrin screening, RNA was extracted from embryonic day 13 hindbrain from rat.

Total RNA was isolated with TRIzol (Invitrogen). RNA was subjected to reverse transcription (RT) with Superscript II First-Strand Synthesis System (Invitrogen).

cDNA was amplified by an initial incubation at $94^{\circ} \mathrm{C}$ for $7 \mathrm{~min}$, followed by 35 cycles of $35 \mathrm{~s}$ denaturation at $94^{\circ} \mathrm{C}, 30 \mathrm{~s}$ primer annealing at $59^{\circ} \mathrm{C}$, and $40 \mathrm{~s}$ for primer extension at $72^{\circ} \mathrm{C}$. Final extension was performed at $72^{\circ} \mathrm{C}$ for $5 \mathrm{~min}$. The PCR products were electrophoresed and analyzed with a $1.5 \%$ agarose gel.

Primer sequences for VAV2 are shown in supplemental Table 1 (available at www.jneurosci.org as supplemental material). Ephrins and Eph primers were generous gifts from Steve Bolsover and Caroline Brenan from the University College London (London, UK). Ephrins and Ephs primers are shown in supplemental Table 2 (available at www.jneurosci. org as supplemental material).

RNA interference experiments. VAV2 small interfering RNA (siRNA) was purchased from Dharmacon (On Target Pool): CAGCAGAGGCAGAGCGUUU; GGUGGAAGGGCGAGACGAA; GUGAAGAUCUACAGCCGGA; and GGAUGGAGCAGUUCGAGAU. VAV2 siRNA used in supplementary experiments was from Invitrogen: CCACAUCACGGAAGCUAAGAAGUUU; AAACUUCUUAGCUUCCGUGAUGUGG). Control siRNA was purchased from Invitrogen. Lipofectamine 2000 (Invitrogen) was used as the transfection reagent.

Assessment of knockdown was achieved by RT-PCR and immunostaining. RNA was isolated from pelleted cells using acid guanidinium phenol chloroform, treated with DNase, and then reverse transcribed. PCR was performed as above, using the VAV2 primers. Three different cycle numbers were used so as to achieve a semiquantitative result.

Schwann cells in 1-cm-diameter laminin-coated wells were treated for 5 h with VAV2 siRNA using Lipofectamine 2000 as the transfection reagent. Twenty-four hours later, Schwann cells were replated on coverslip fragments coated with PDL. After $24 \mathrm{~h}$, the coverslip fragments were 
inverted onto astrocytic monolayers for migration assays for an additional $24 \mathrm{~h}$.

Western immunoblotting. Briefly, culture medium was taken off from the cultured cells. The cells were washed with ice-cold PBS before being scrapped from the substratum with cold lysis buffer (50 mM HEPES, 150 $\mathrm{mm} \mathrm{NaCl}, 10 \%$ glycerol, $1.5 \mathrm{~mm} \mathrm{MgCl}_{2}, 1 \mathrm{~mm}$ EDTA, and protease inhibitor cocktail). The suspension was collected and passed through a 30 gauge needle three times. The lysate was briefly centrifuged with $1000 \times$ $g$ for $5 \mathrm{~min}$ to remove cell debris. The supernatant was then ultracentrifuged at $100,000 \times g$ for $1 \mathrm{~h}$ at $4^{\circ} \mathrm{C}$. The supernatant, which contains soluble proteins, was transferred to a clean Eppendorf. The pellets were dissolved in lysis buffer again with $1 \%$ Triton X-100. Protein concentration was determined using BCA Protein Assay kit (reducing agent compatible; Pierce).

Twenty micrograms of proteins were electrophoresed in a $4-20 \%$ Tris-Bis polyacrylamide gel (Invitrogen) at $120 \mathrm{~V}$ for $70 \mathrm{~min}$. After separation by electrophoresis, proteins were transferred to polyvinylidene difluoride membrane (GE Healthcare) at $4^{\circ} \mathrm{C}$ for $3 \mathrm{~h}$ at $35 \mathrm{~V}$. Membranes were washed twice in TBS containing $0.05 \%$ Tween 20 (TBS/T) and blocked with 5\% skimmed milk (Marvel) in TBS/T. It was then incubated with primary antibodies in TBS/T (with $5 \%$ skimmed milk) overnight at $4^{\circ} \mathrm{C}$. Primary antibodies used were as follows: monoclonal anti-ephrin $\mathrm{A} 5$ antibody (1:1000; Abcam) and rabbit polyclonal anti-EphA4 antibody (1:2500; generous gift from Dr. Wilkinson). Membranes were washed five times in TBS/T and incubated for $1.5 \mathrm{~h}$ in TBS/T containing peroxidase-conjugated secondary antibodies (1:75,000; Vector Laboratories). Membranes were washed five times in TBS/T, and proteins were visualized using a chemiluminescent substrate (ECL Plus; GE Healthcare). After visualization with the first set of antibodies, the membrane was stripped with $0.1 \mathrm{M}$ glycine, $\mathrm{pH} 2.5$, with $0.05 \%$ Tween 20 at $37^{\circ} \mathrm{C}$ for $30 \mathrm{~min}$. The membrane was washed thoroughly with an ample amount of TBS/T before probing with the second set of antibodies.

Quantification of immunostaining. NIH Image J software was used to measure the integrated pixel density of staining for Schwann cells in each group. For each cell, signal intensity of pFAK or pVAV2 was calculated and background intensity was subtracted. Signal intensity for each cell was then standardized to the corresponding internal p75 immunostaining levels to take account of variation in cell size and morphology. An average of the signal intensity ratio of $\mathrm{pFAK} / \mathrm{p} 75$ or $\mathrm{pVAV} 2 / \mathrm{p} 75$ were then calculated for each group. The values were then normalized to the value obtained for the control group. The experiments were repeated at least three times, and total average was calculated.

For quantification of Schwann cells in boundary assays, Schwann cells were identified with p75 staining and astrocytes with GFAP. Schwann cells in direct contact with hypertrophied astrocytes were identified with Schwann cells in the same field that contacted only other Schwann cells as control cells. For each intensity measurement for Schwann cells in contact, a noncontacting control cell measurement from the same field was identified. The signal intensity was standardized to the corresponding p75 levels for each cell to take account of variation in cell size and morphology. Signal intensity for $\mathrm{pFAK} / \mathrm{pVAV}$ was given as a ratio to the $\mathrm{p} 75$ staining level for each cell. pFAK/pVAV2 readings in Schwann cells contacting astrocytes were then normalized to noncontacting control cell values. The experiments were repeated three times, and a total average was calculated.

Statistical analysis. For Student's $t$ test, in Schwann cell migration assays involving two groups, the number of cells migrating from the edge of coverslip was compared with that of the control at the same distance. For comparisons involving more than two groups, one-way ANOVA test was performed, followed by the Bonferroni's post hoc test to compare the different pairs with each other. Throughout, ${ }^{\star} p<0.05,{ }^{* *} p<0.01$, and ${ }^{* * *} p<0.001$.

\section{Results}

\section{Eph/ephrin expression in Schwann cells and astrocytes}

The profile of Eph and ephrins expressed by Schwann cells has not been previously documented. We characterized the ephrinA profile in purified astrocytic cultures (postnatal days 1-3) and
Table 1. Expression of ephrin as in astrocytes

\begin{tabular}{lc}
\hline Ephrins & Detected \\
\hline EphrinA1 & + \\
EphrinA2 & + \\
EphrinA3 & + \\
EphrinA4 & + \\
EphrinA5 & + \\
\hline
\end{tabular}

Table 2. Expression of ephrins and Ephs in Schwann cells

\begin{tabular}{lllc}
\hline Ephrin & Detected & Ephs & Detected \\
\hline Control $\beta$-actin & + & EphA1 & - \\
EphrinA1 & + & EphA2 & + \\
EphrinA2 & + & EphA3 & - \\
EphrinA3 & + & EphA4 & + \\
EphrinA4 & + & EphA5 & - \\
EphrinA5 & + & EphA6 & - \\
& & EphA7 & + \\
EphrinB1 & & EphA8 & - \\
EphrinB2 & + & EphB1 & - \\
EphrinB3 & - & EphB2 & + \\
& - & EphB3 & + \\
\hline
\end{tabular}

demonstrated that all ephrinA mRNAs are present in astrocytes (Table 1). The RT-PCR findings are in agreement with other studies that have previously shown the presence of ephrinAs in the astrocytes (Winslow et al., 1995; Sobel, 2005). We further characterized the ephrin and Eph profile in purified Schwann cells (postnatal days 1-3) showing that Schwann cells have complementary sets of receptors on their surface that may interact with ephrinAs on astrocytes (Table 2).

\section{EphrinAs inhibit Schwann cell migration}

Following the hypothesis that astrocyte-produced ephrins might inhibit Schwann cell migration, we assayed the effect of clustered ephrins in solution on Schwann cell migration on laminin (1 $\mu \mathrm{g} / \mathrm{ml}$ ) using the inverted coverslip assay (Fok-Seang et al., 1995; Wilby et al., 1999). We tested the effect of clustered ephrinAs and ephrinBs, using $16 \mathrm{~h}$ migration assays in the presence of $10 \mu \mathrm{g} / \mathrm{ml}$ ephrin. Of the ephrins that were tested, ephrinA1, ephrinA3, and ephrinA5 reduced migration, with ephrinA5 having the greatest effect (Fig. $1 A-C$ ). We confirmed using immunocytochemistry that ephrinA5 is abundantly present on astrocyte cultures (Fig. 1D). In all subsequent experiments in this study, therefore, clustered ephrinA5 was used to examine the mechanism of ephrin action. Other ephrins tested, including ephrinB1, ephrinB2, and ephrinB3, did not affect Schwann cell migration.

\section{EphAs in Schwann cells mediate the inhibitory effect of astrocyte ephrinAs}

From the Schwann cell Eph screen reported above, the possible receptors for ephrinA5 are EphA4, EphA2, and EphA7. We confirmed the presence of EphA4 and EphA2 in purified Schwann cell cultures using immunocytochemistry (Fig. $2 A, B$ ). To investigate whether astrocyte-produced ephrinAs act on Schwann cell receptors such as EphA4 to inhibit their migration, we performed assays in the presence of soluble EphA4-Fc, which has been shown in previous studies to act as a blocker of the action of ephrinAs (Goldshmit et al., 2004). We first examined Schwann cell migration over confluent astrocyte monolayers using $48 \mathrm{~h}$ inverted coverslip migration assays, with the EphA4-Fc refreshed after $24 \mathrm{~h}$. As in previous experiments, Schwann cell mi- 
A

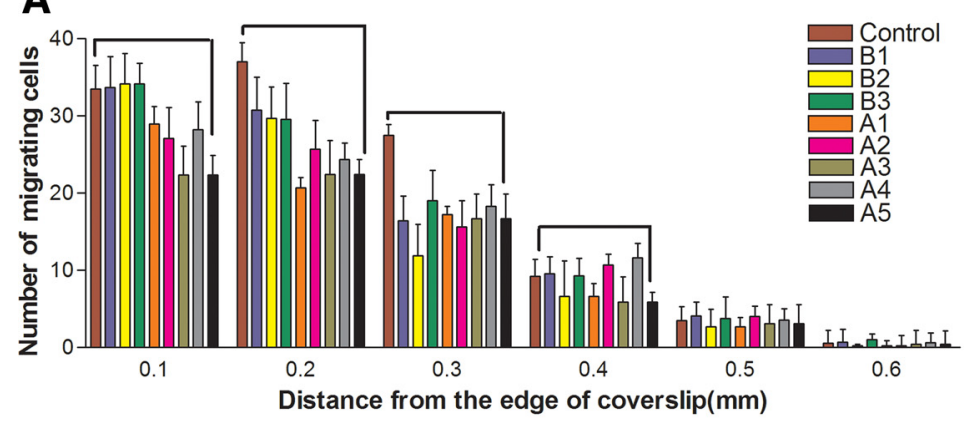

B

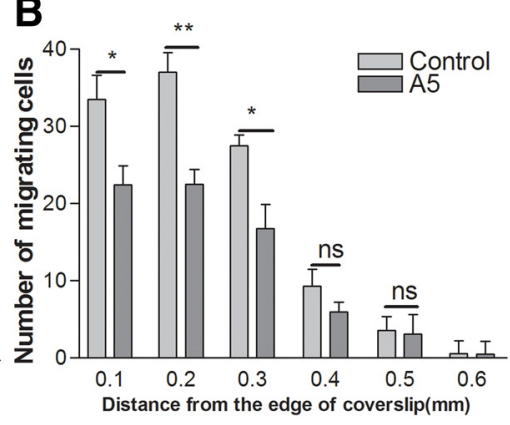

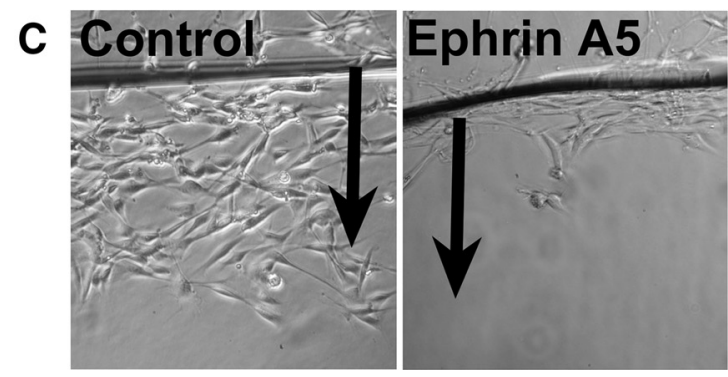
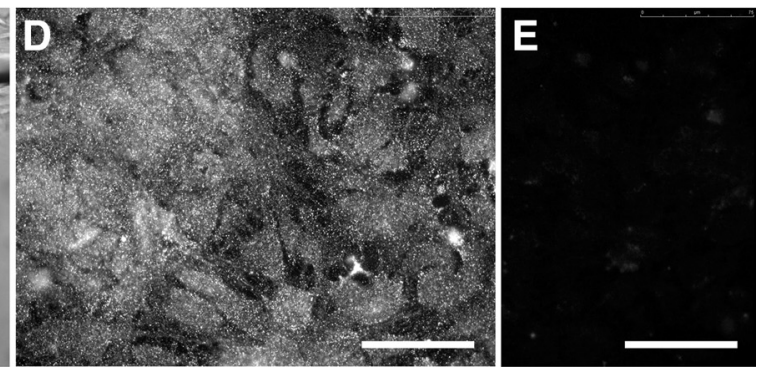

Figure 1. The effect of clustered ephrins on Schwann cell migration on laminin. $A$, EphrinA1, ephrinA3, and ephrinA5 reduce Schwann cell migration on laminin with the greatest reduction caused by ephrinA5. Clustered ephrinBs did not affect Schwann cell migration on laminin. B, Clustered ephrinA5 reduces the number of Schwann cells migrating from the edge of coverslip significantly. $n=3 ; t$ test, ${ }^{*} p<0.05$. C, Images of Schwann cell migration on laminin in the control nontreated and ephrinA5-treated group. Arrows point to the direction of cell migration from the edge of coverslip. $\boldsymbol{D}, \boldsymbol{E}$, Immunostaining for ephrinA5 on astrocytic monolayers $(\boldsymbol{D})$ and its corresponding negative control $(\boldsymbol{E})$. Scale bars, $75 \mu \mathrm{m}$.

gration on astrocytes was very limited. The presence of EphA4-Fc $(10 \mu \mathrm{g} / \mathrm{ml})$ increased the number of Schwann cells migrating on astrocytic monolayers (Fig. 2C). We further assessed the effect of soluble EphA2-Fc on Schwann cell migration on astrocytes because EphA2 mRNA was also detected in the screen for possible receptors; however, no effect was seen using this peptide on the migratory behavior of cells in the assay (Fig. 2D). Similarly, the presence of EphA7 was also confirmed using immunostaining. However, the addition of EphA7-Fc had no effect on Schwann cell migration on astrocytes (supplemental Fig. 2, available at www.jneurosci.org as supplemental material).

Quantification of immunostaining of EphA receptors showed higher levels of EphA4 receptor on Schwann cells compared with EphA2 and EphA7 (supplemental Fig. 3, available at www. jneurosci.org as supplemental material).

Next we performed a Schwann cell-astrocyte confrontation assay, which more closely models the interface formed between the two cell types after transplantation (Wilby et al., 1999; Lakatos et al., 2000). In this assay, dense suspensions of Schwann cells and astrocytes are plated onto PDL-coated coverslips using a straight-edged coverslip. This produces confluent Schwann cell and astrocyte monolayers with straight edges and a $<0.5 \mathrm{~mm}$ gap between them. The monolayers grow together in a few days, and, because the cell types are resistant to mixing, a clear straight Schwann cell-astrocyte interface results with occasional Schwann cells trapped among the astrocytes (Fig. 3A). We applied EphA4-Fc peptide for $48 \mathrm{~h}$ during the time when the monolayers came together (Fig. 3B). This produced a marked increase in the number of Schwann cells that had penetrated within astrocytic territory, mostly within the $100 \mu \mathrm{m}$ from the edge of the astrocytic boundary (Fig. 3C).

In addition to blocking the interaction of ephrinAs with EphA receptors, EphA4-Fc in solution can cause reverse signaling with the ephrin as receptor. We therefore further assessed the effect of soluble EphA4-Fc $(10 \mu \mathrm{g} / \mathrm{ml})$ on Schwann cell migration on laminin $(1 \mu \mathrm{g} / \mathrm{ml})$ over $24 \mathrm{~h}$ using the inverted coverslip assay. Application of this peptide had no effect on the Schwann cell migration, demonstrating that the effect of EphA4 peptide on Schwann cell migration on astrocytic monolayers and in boundary assays is not attributable to reverse signaling via ephrins on Schwann cells (Fig. 3D). We cannot exclude an additional effect of EphA4 peptide on astrocytes, and previous experiments have shown that EphA4 receptor is involved in astrocytosis and EphA4 knock-out mice show reduced glial scar formation (Goldshmit et al., 2004). Our data suggest that astrocyte-produced ephrinAs (particularly ephrinA5) act on Schwann cell EphAs to mediate the inhibitory effect of astrocytes on Schwann cell migration and intermixing of the two cell types.

Because both Schwann cells and astrocytes express ephrinA5 and EphA4, it is necessary to see different levels of expression of these molecules on Schwann cells and astrocytes if they are to play a part in establishing a boundary between the two cell types. Western immunoblotting for proteins in membrane fraction demonstrated that astrocytes express higher levels of ephrinA5, with Schwann cells expressing higher levels of EphA4 (Fig. 3E). Coomassie Brilliant Blue confirmed the equal amount of protein loading. This further supports a role of differential expression of EphrinA5-induced repulsion in establishing the boundary between the astrocytes and Schwann cells.

\section{Signaling from EphA receptor in Schwann cells}

We investigated the possibility that VAV proteins are the signaling pathways downstream from EphA4 in Schwann cells. VAV2 has been shown previously to be recruited and phosphorylated after activation of EphA receptors (Cowan et al., 2005). The main VAV present in Schwann cells has been shown to be VAV2 (Yamauchi et al., 2004). We first confirmed this previous finding by demonstrating the presence of VAV2 in our Schwann cells by immunostaining (Fig. 4A, B,F). Activation of VAV2 can be detected using antibodies that recognize the phosphorylated form 
of the molecule. We therefore assessed the effect of the addition of soluble clustered ephrinA5 on VAV2 phosphorylation in Schwann cells cultured on laminin. Addition of clustered ephrinA5 led to an increase in VAV2 phosphorylation at the 10 min time point (Fig. 4A,B). Quantification of the immunostaining revealed a $43.7 \%$ increase in pVAV2 levels after treatment with the clustered ephrinA5 $\left(n=3\right.$; $t$ test, $\left.{ }^{\star} p<0.05\right)$.

If astrocyte-produced ephrinAs are responsible for inhibiting Schwann cell migration, it should be possible to see increased phosphorylation of VAV2 in Schwann cells that are in contact with astrocytes. We therefore examined the phosphorylation status of VAV2 in cultures in which we had set up boundaries between Schwann cells and astrocytes. We found that Schwann cells directly in contact with hypertrophied astrocytes show higher levels of pVAV2 compared with cells not in contact with astrocytes within the same field (Fig. 4D-F). Quantification of immunostaining for pVAV2 showed a $38.5 \%$ increase in Schwann cells in contact with hypertrophied astrocytes compared with that of control $(n=3 ; t$ test, $\left.{ }^{\star *} p<0.01\right)$. Levels of pVAV2 in each cell was normalized to the p75 immunostaining to ensure that the increase in pVAV2 immunoreactivity was not attributable to artifactual changes in Schwann cell morphology.

These results suggest that astrocyteproduced ephrinAs cause Eph-mediated phosphorylation of VAV2 in Schwann cells where the cell types come into contact. We therefore investigated whether reduction of levels of VAV2 using siRNA treatment of Schwann cells would affect Schwann cell-astrocyte interactions. Knockdown of VAV2 was assessed using RTPCR and immunostaining of the cells (Fig. 5A-C). Both techniques demonstrated efficient knockdown of VAV2 at $48 \mathrm{~h}$ after application of the siRNA, but no change was observed using control siRNA or in the levels of the housekeeping gene hypoxanthine-guanine phosphoribosyltransferase. Assessment of VAV2 knockdown at $48 \mathrm{~h}$ by immunostaining shows protein levels of $\sim 50 \%$ of control at the time of start of the migration assays $(n=$ 3 ; $t$ test, $\left.{ }^{\star} p<0.05\right)$.

At $48 \mathrm{~h}$ after applying the siRNA to Schwann cells, their migration on astrocytic monolayers was assessed using the inverted coverslip assay. VAV2 siRNA-treated Schwann cells showed a marked increase in cell migration on the surface of astrocytes compared with that of control siRNA-treated cells (Fig. 5D-F). This finding further strengthens the evidence that
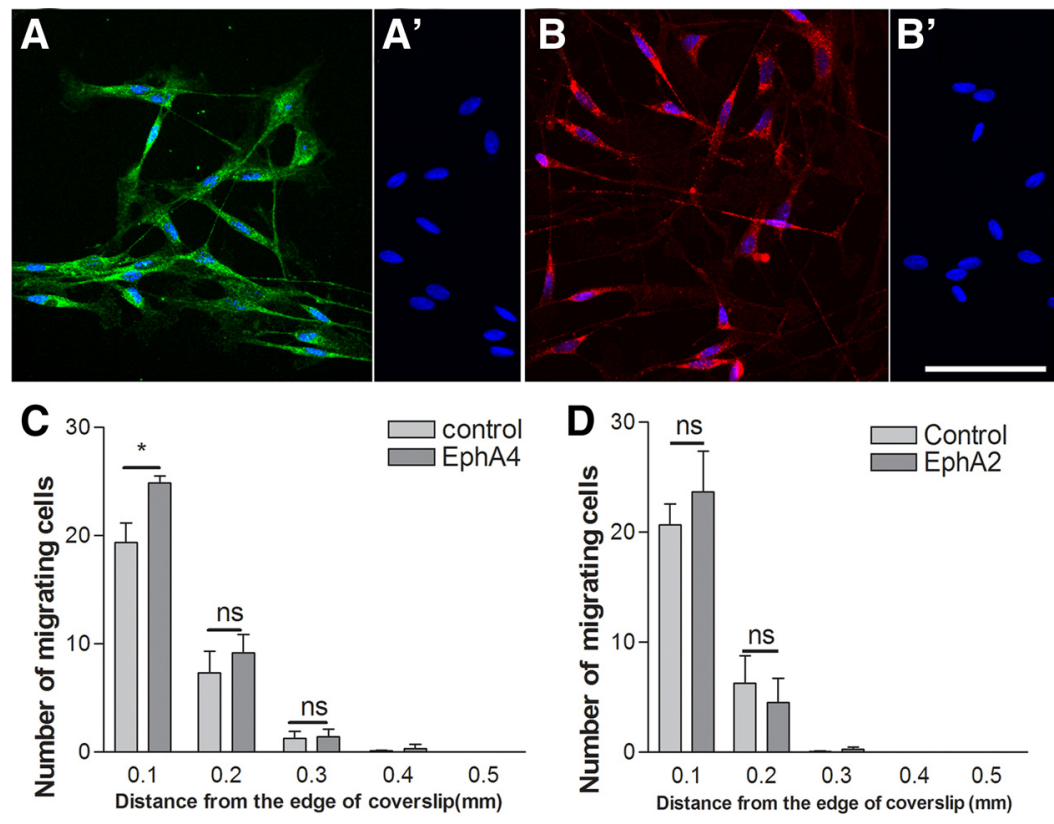

Figure 2. The effect of Eph-Fc in solution on Schwann cell migration on astrocytes. $\boldsymbol{A}-\boldsymbol{B}^{\prime}$, Immunostaining for EphA4 $(\boldsymbol{A})$ and EphA2 $(\boldsymbol{B})$ in postnatal Schwann cells and their corresponding negative controls $\left(\boldsymbol{A}^{\prime}, \boldsymbol{B}^{\prime}\right)$. DAPI nuclear staining is blue. Scale bar, $75 \mu \mathrm{m}$. C, D, EphA4 -Fc improves Schwann cell migration on astrocytes near the coverslip in the Schwann cell migration assay, but EphA2-Fc did not have any effect. $n=3 ; t$ test, ${ }^{*} p<0.05$.
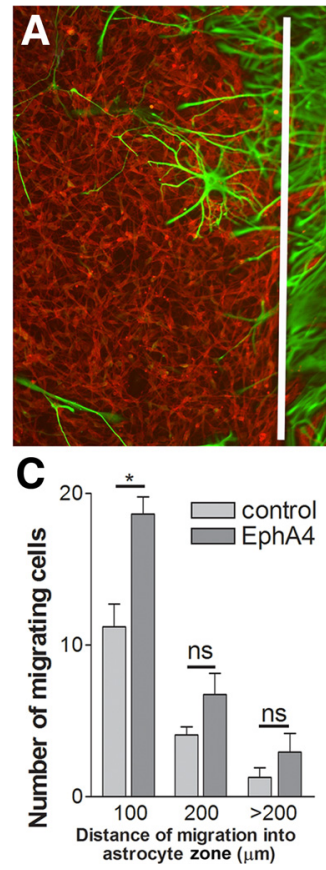
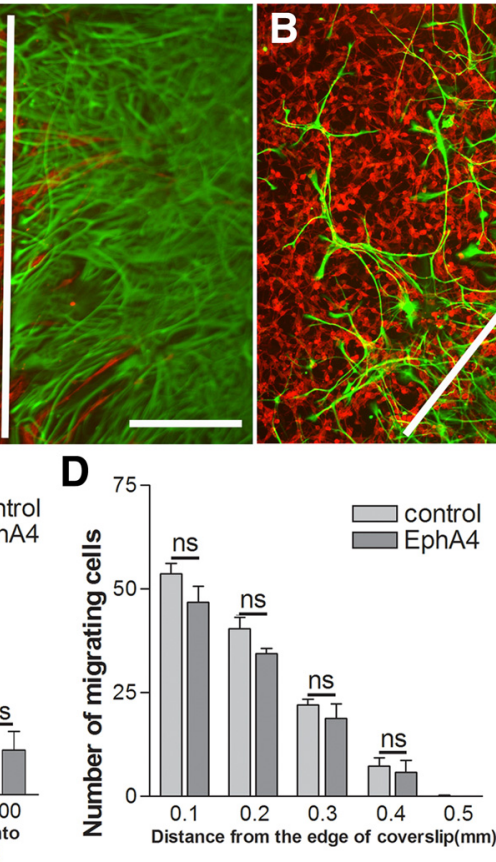

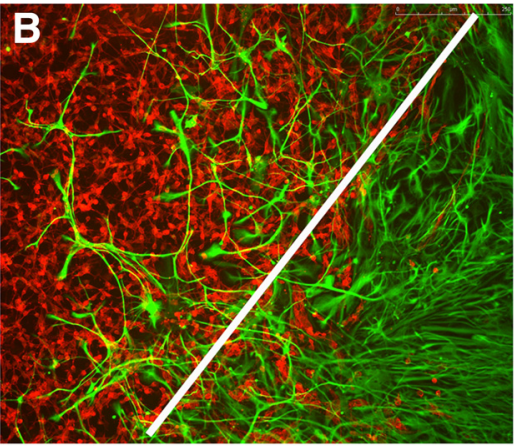

$\mathbf{E}$
Figure 3. The effect of EphA4-Fc in solution on Schwann cell intermingling with astrocytes in the boundary assay. $\boldsymbol{A}, \boldsymbol{B}, S$ Schwann cells labeled for p75 (red) and astrocytes for GFAP (green) in the boundary assay in control ( $\boldsymbol{A}$ ) and EphA4 -Fc-treated ( $\boldsymbol{B}$ ) confrontation cultures The white lines depicts the boundaries between the astrocyte cell front and Schwann cells. Scale bar, $250 \mu \mathrm{m}$. C, EphA4-Fc (10 $\mu \mathrm{g} / \mathrm{ml})$ increases Schwann cell-astrocyte intermingling in the boundary assay. $n=3 ; t$ test, ${ }^{*} p<0.05$. D, Schwann cell migration on laminin is not affected by EphA4-Fc in solution, excluding reverse signaling through Schwann cell ephrins. $n=3$. $\boldsymbol{E}$, Immunoblotting of ephrinA5 and EphA4 on the membrane preparations from Schwann cells (SC) and astrocytes (AS). It demonstrates a higher level of ephrinA5 on astrocytes than Schwann cells. A reverse trend is seen for EphA4 that shows a higher level on Schwann cells than astrocytes. Coomassie Brilliant Blue staining on the blots demonstrates equal loading of proteins.

VAV2 mediates the ephrin-induced reduction in Schwann cell migration and is in agreement with previous studies demonstrating the role of VAV proteins as downstream effectors of Eph activation (Cowan et al., 2005; Hunter et al., 2006). 

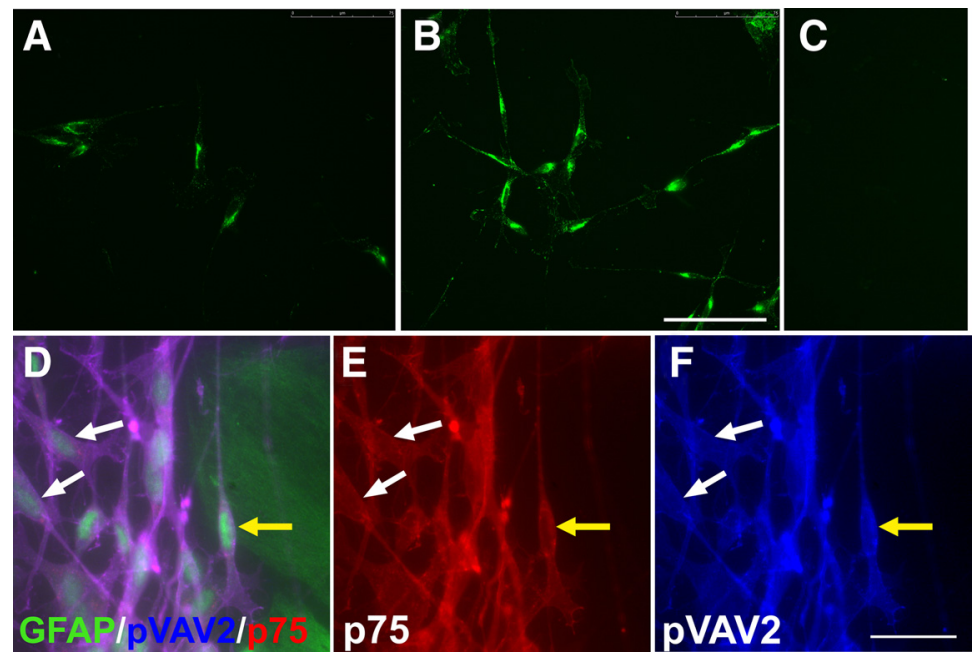

Figure 4. The effect of ephrinA5 on phosphorylation of VAV2 in Schwann cells. A-C, Immunostaining for phosphorylated VAV2 in nontreated control (A), EphrinA5-treated Schwann cells $(\boldsymbol{B})$, and negative control (C). Scale bar, $75 \mu \mathrm{m}$. Addition of clustered ephrinA5 to Schwann cells plated on laminin leads to an increase in the levels of pVAV2 at $10 \mathrm{~min}$. $\boldsymbol{D}-\boldsymbol{F}$, Immunostaining of Schwann cells labeled for p75 (red) in contact with GFAP-labeled (green) astrocytes (D). $\boldsymbol{E}$ and $\boldsymbol{F}$ show the corresponding p75 and phosphorylated VAV2 staining, respectively. The yellow arrow points to a Schwann cell in contact with astrocytes. There are also piled up Schwann cells in contact with astrocytes adjoining it. The white arrows point to noncontacting Schwann cells. Schwann cells in contact with astrocytes have increased levels of phosphorylated VAV2 compared with control noncontacting cells. Scale bar, $25 \mu \mathrm{m}$.
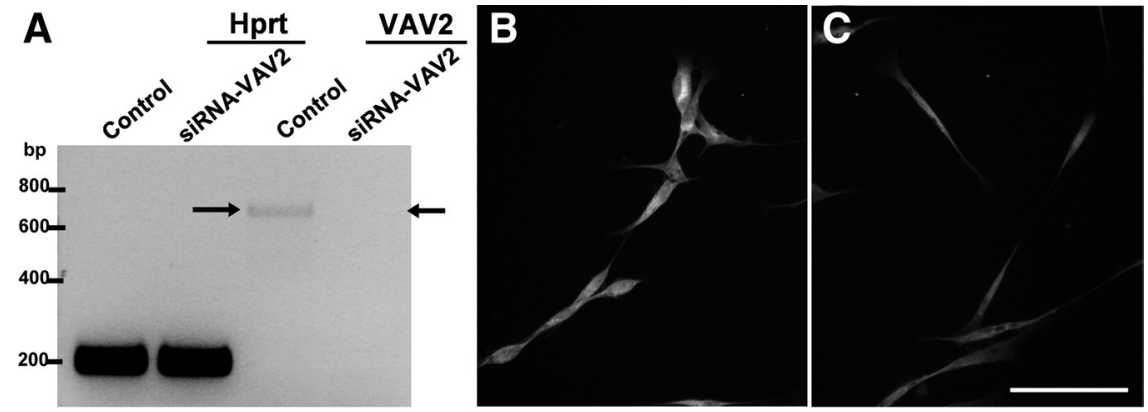

D
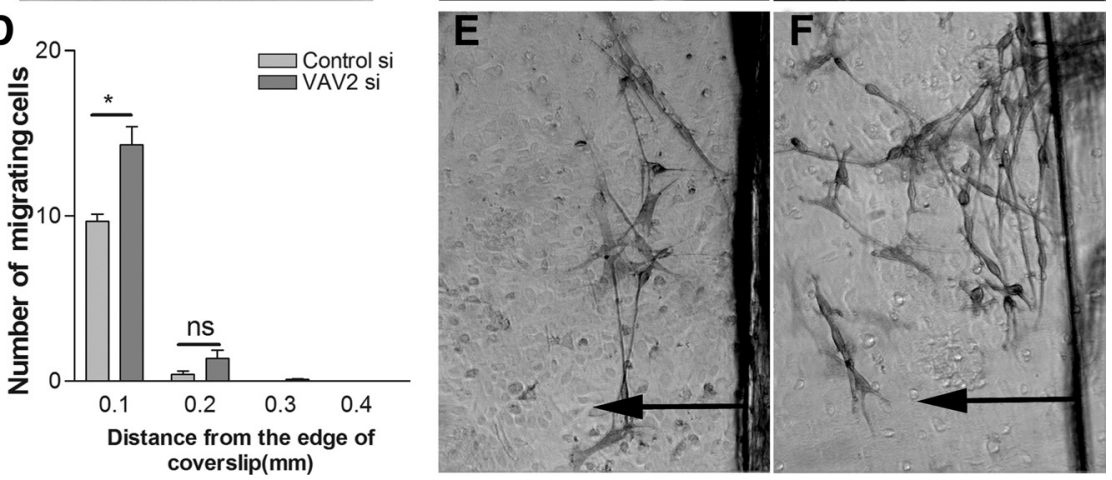

Figure 5. The effect of VAV2 knockdown on Schwann cell migration on astrocytes. $A$, Assessment of VAV2 knockdown at $48 \mathrm{~h}$ using RT-PCR. Note the complete absence of a 663 bp band (arrow) corresponding to VAV2 in the VAV2 siRNA-treated group only. $\boldsymbol{B}, \boldsymbol{C}$, VAV2 immunostaining in control (B) and VAV2 siRNA-treated cells ( $($ ). Assessment of VAV2 knockdown at $48 \mathrm{~h}$ by immunostaining shows protein levels of $\sim 50 \%$ of control at the time of start of the migration assays. $D$, Knockdown of VAV 2 increases the number of Schwann cells migrating from the edge of coverslip compared with control cells. $n=3 ; t$ test, ${ }^{*} p<0.05 . E, F, S$ chwann cell migration on astrocytic monolayers in the control siRNA-treated $(\boldsymbol{E})$ and VAV2 siRNA-treated $(\boldsymbol{F})$ Schwann cells. Arrows point to the direction of cell migration.

\section{Ephrins affect Schwann cell integrins}

Integrins play a major role in Schwann cell migration (Milner et al., 1997). In the experiments above, we have studied Schwann cell migration on laminin, which has been shown previously to be a $\beta 1$ integrin-dependent phenomenon (Milner et al., 1997).
We have shown that Schwann cell migration on astrocytes is also largely dependent on the $\beta 1$ class of integrins but not $\beta 3$ integrins (supplemental Fig. 1, available at www.jneurosci.org as supplemental material). Eph and ephrins have been shown previously to influence integrins, and a direct effect of EphA activation on the phosphorylation of FAK and on integrin function has been shown previously in epithelial cells and neurons (Miao et al., 2000; Bourgin et al., 2007). It is therefore likely that EphA activation inhibits Schwann cell migration through modulation of integrin function. We therefore investigated the effect of ephrinA5-induced activation of Eph receptors on the modulation of Schwann cell integrins. Integrin downstream signaling passes via FAK, and phosphorylation of FAK occurs when activated integrins link to their ligand. Phosphorylation of FAK at tyrosine residue 397 has been shown previously to be associated with integrin activation (Sawai et al., 2005), and Eph receptors have been shown to be able to reduce phosphorylation of FAK (Miao et al., 2000; Bourgin et al., 2007). To assess the effect of ephrinA5 on Schwann cell integrin signaling, the influence of ephrinA5 on the phosphorylation of FAK was determined. Addition of soluble clustered ephrinA5 to Schwann cells cultured on laminin $(1 \mu \mathrm{g} / \mathrm{ml})$ led to $31.3 \%$ reduction in the phosphorylation of FAK within 10 min (Fig. $6 A, B)(n=3$; $t$ test, $\left.{ }^{\star} p<0.05\right)$, demonstrating that Eph activation in Schwann cells affects integrin signaling.

From the preceding result, if the inhibition of migration of Schwann cell migration by astrocytes is mediated by ephrins, FAK phosphorylation should be reduced where the two cell types are in contact. We therefore set up confrontation cultures in which a Schwann cell-astrocyte boundaries form, where pFAK levels in Schwann cells at the boundary edge are measured after immunostaining. We find that Schwann cells directly in contact with astrocytes show reduced pFAK levels compared with Schwann cells in the same cultures and the same field of view that are not in contact with astrocytes (Fig. 6C,D). Quantification of pFAK levels in Schwann cells in contact with astrocytes showed a $36.6 \%$ reduction in the levels of pFAK compared with that of noncontacting Schwann cells $(n=3 ; t$ test, ${ }^{* *} p<0.01$ ). Levels of pFAK for each cell were normalized to p75 immunostaining to ensure that the decrease in pFAK immunoreactivity was not attributable to artifactual changes in Schwann cell morphology. This finding suggests that astrocyteproduced ephrin affects Schwann cell integrin signaling. 

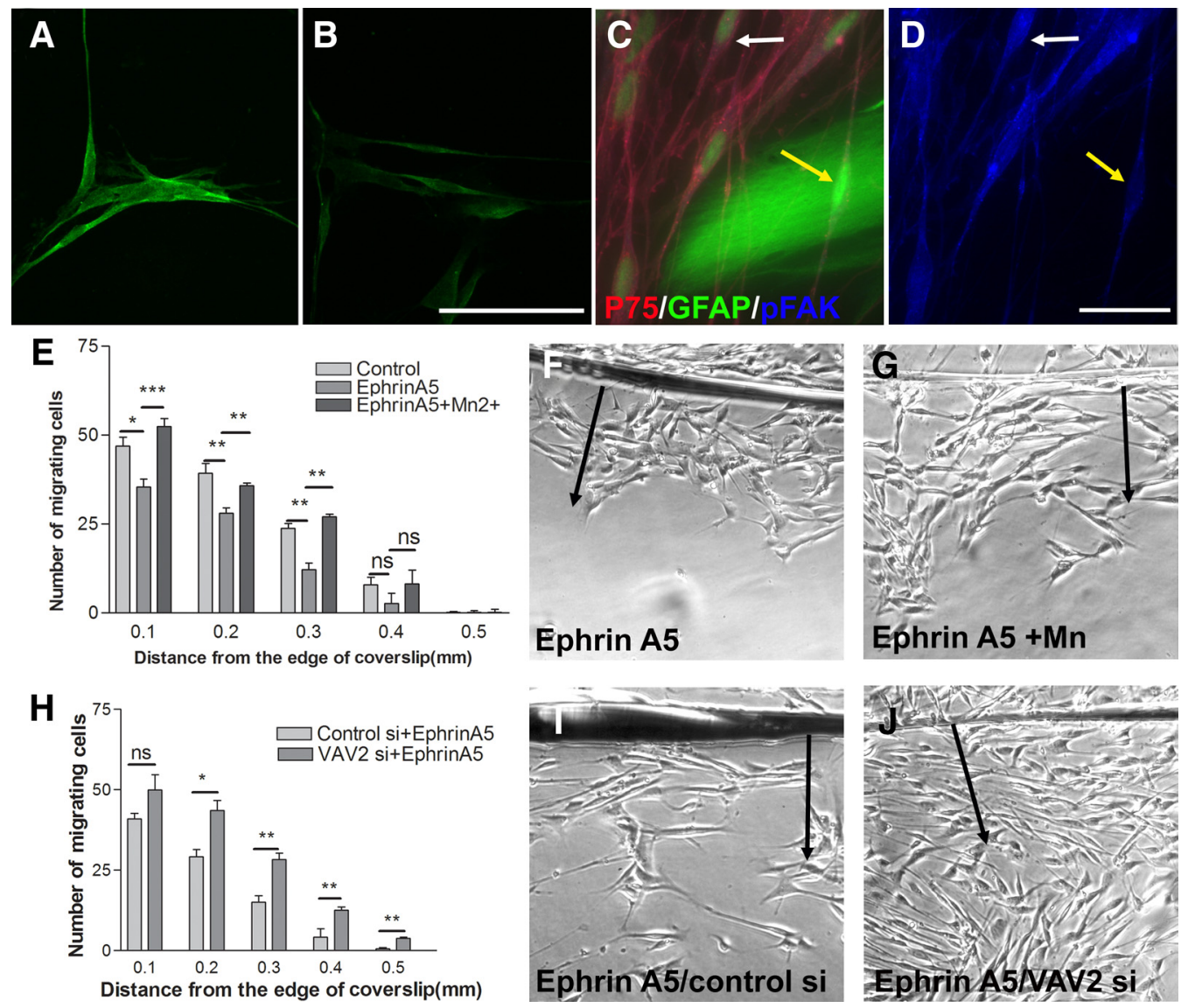

Figure 6. The effect of ephrins on integrin-mediated signaling and migration. $\boldsymbol{A}, \boldsymbol{B}, \mathrm{pFAK}$ immunostaining in nontreated controls $(\boldsymbol{A})$ and clustered ephrinA5-treated cells $(\boldsymbol{B})$. Addition of clustered ephrinA5 to Schwann cells plated on laminin reduces pFAK levels. Scale bar, $75 \mu \mathrm{m} . \mathbf{C}, \mathbf{D}$, Immunostaining of Schwann cells labeled for p75 in contact with GFAP-labeled astrocytes (C) and the corresponding phosphorylated FAK staining (D). Schwann cells in contact with hypertrophied astrocytes have decreased pFAK levels compared with control noncontacting Schwann cells. The yellow arrow points to a Schwann cell in contact with astrocytes and the white arrow to a noncontacting Schwann cell. Scale bar, $25 \mu \mathrm{m}$. E, Addition of integrin activating Mn ${ }^{2+}(500 \mu \mathrm{M})$ to Schwann cells migrating in the presence of clustered ephrinA5 reverses the inhibitory effect of ephrinA5 on migration. $n=5 ; A N O V A,{ }^{*} p<0.05$. $F, G$, Images of the migration assay after addition of clustered ephrinA5 in the absence $(\boldsymbol{F})$ and presence $(\boldsymbol{G})$ of $\mathrm{Mn}^{2+}$. $\boldsymbol{H}$, VAV2 knockdown in Schwann cells abolishes the inhibitory effect of ephrinA5 on Schwann cell migration on laminin. $n=3$; ANOVA, ${ }^{*} p<0.05 . I, J$, Images of Schwann cell migration on laminin in the presence of clustered ephrinA5 in control siRNA $(I)$ and VAV2 siRNA $(J)$ treated cells.

Integrin activating agents such as $\mathrm{Mn}^{2+}$ have been shown previously to increase the affinity of the integrins to their ligands (Mould et al., 1995) and to reverse the inhibitory effect of molecules intercepting integrin function (Miao et al., 2000; $\mathrm{Hu}$ and Strittmatter, 2008). We therefore asked whether activation of integrins with $\mathrm{Mn}^{2+}$ would reverse the inhibitory effect of ephrinA5 on Schwann cell migration on laminin. Soluble clustered EphrinA5 was applied to Schwann cells in the presence or absence of $500 \mu \mathrm{M} \mathrm{Mn}^{2+}$, and migration was measured using the inverted coverslip assay. The addition of $\mathrm{Mn}^{2+}$ reversed the inhibitory effect of clustered EphrinA5 on Schwann cell migration on lami$\operatorname{nin}($ Fig. $6 E-G$ ).

In the experiments above, we showed that the inhibitory effect of astrocytes on Schwann cell migration can be overcome by blocking VAV2 signaling (Fig. 5A-F). Experiments from other studies have shown that Eph-mediated effects are abolished in VAV2/VAV3 knock-out animals (Cowan et al., 2005). We therefore asked whether a deficiency of VAV2 blocks the effect of ephrinA5 on integrin-mediated migration of Schwann cells on laminin. VAV2 knockdown was achieved using the same paradigm as was used for the migration assay on astrocytes. At $48 \mathrm{~h}$ after application of siRNA, the Schwann cell migration assay was performed in the presence of clustered ephrinA5. VAV2 knockdown abolished the inhibitory effect of ephrinA5 on Schwann cell migration on laminin (Fig. $6 H-J$ ). We further verified this result using a different independent strand of siRNA against VAV2 to ensure that the observed results were not attributable to off-target effects (supplemental Fig. 4, available at www.jneurosci.org as supplemental material). VAV2 knockdown using this strand, in the presence of clustered ephrinA5, increased Schwann cell migration as before, supporting a role for VAV2 in inhibiting integrin-mediated migration on laminin.

Together, our results suggest that ephrinAs produced by astrocytes are involved in inhibition of Schwann cell migration and that this effect is mediated through EphA receptors on Schwann cells, leading to VAV2 signaling and interception of integrin function.

\section{Discussion}

Ephs and ephrins play important roles in cell segregation and tissue boundary formation (Mellitzer et al., 1999) and in the guidance of neural crest migration (Krull et al., 1997). Schwann cells are neural crest derived (Jessen and Mirsky, 2005), so we hypothesized that they might retain their ephrin-mediated guidance mechanisms. The inability of Schwann cells to mingle with astrocytes might therefore involve Eph/ephrin interactions.

We investigated the types of ephrin produced by astrocytes and the Eph receptors on Schwann cells. Both cells produce sev- 
eral Ephs and ephrins, with astrocytes producing ephrinA1-ephrinA5 and Schwann cells producing EphA2, EphA4, and EphA7 as potential receptors. Our findings are in agreement with other studies that have reported the presence of ephrinAl (Sobel, 2005), ephrinA3 (Sobel, 2005), and ephrinA5 (Winslow et al., 1995 ) in astrocytes. Our Schwann cells were 96.5\% pure based on S100 staining, so these results are unlikely to be influenced by fibroblast contamination. Applying the various astrocyte ephrins to Schwann cells, we saw that ephrinA1, ephrinA3, and ephrinA5 were able to inhibit Schwann cell migration on a laminin surface. There is considerable promiscuity of binding between Eph and ephrin receptors, so these ephrins could have several possible Eph receptors (Haramis and Perrakis, 2006). EphA4 has been shown previously to play an important role after spinal cord injury. EphA4 knock-out animals show enhanced axon regeneration and less glial scarring after spinal cord injury (Goldshmit et al., 2004), and EphA4-blocking peptides have been shown to enhance spinal axon regeneration (Fabes et al., 2007). Based on this, we hypothesized that EphAs, such as EphA4, on Schwann cells may mediate the inhibitory effect of ephrinAs. This receptor can be blocked by EphA4-Fc, so we tested the ability of this compound to affect Schwann cell migration on astrocyte monolayers and the intermingling of Schwann cells and astrocytes. In both assays, soluble EphA4-Fc increased Schwann cell migration and intermingling. This result supports the hypothesis that astrocyte-produced ephrinAs inhibit Schwann cell migration via the EphA receptors. It is important to notice that EphA4-Fc, in addition to blocking ephrinA binding to EphA4, may also disrupt the binding of ligands to other EphA receptors as a result of the promiscuity in the receptor-ligand binding. Therefore, the effect of this peptide on other EphA receptors cannot be excluded. However, application of other EphAs, including EphA2 and EphA7, did not affect Schwann cell migration or intermingling with astrocytes, supporting a more prominent role of EphA4.

In addition, because both Schwann cells and astrocytes express ephrinA5 and EphA4, we performed a comparative Western immunoblotting for these two proteins in these two cell types and demonstrated that the astrocytic surface has higher levels of ephrinA5 compared with Schwann cells, further supporting the involvement of ephrin-induced repulsion in boundary formation between astrocytes and Schwann cells.

Various signaling pathways have been suggested for downstream signaling from Eph receptors, with strong recent evidence implicating VAV proteins (Cowan et al., 2005). VAV proteins belong to that guanidine nucleotide exchange factor family, which has been shown to modulate the activity of Rho, Rac, and Cdc42 (Hornstein et al., 2004). They may either promote cell migration by promoting Racl activation (Hunter et al., 2006) or inhibit migration by activation of RhoA (Yamauchi et al., 2004). VAV2 is the main VAV subtype present in Schwann cells, and BDNF affects Schwann cell behavior via VAV2 and RhoA (Yamauchi et al., 2004). We therefore investigated whether VAV2 is the pathway through which ephrinA5 affects Schwann cell migration. We found that ephrinA5 application increases the phosphorylation of VAV2 in Schwann cells. Moreover, where Schwann cells are in contact with astrocytes, there is increased phosphorylation of VAV2 within them. These findings are in agreement with a previous study showing recruitment and phosphorylation of VAV GEFs after the activation of Eph receptors (Cowan et al., 2005). Because cells from VAV2/3 knock-out animals have been shown to lose responsiveness to Eph activation (Cowan et al., 2005), we asked whether the VAV2 is required for the astrocyte-mediated inhibition of Schwann migration. We demonstrate that VAV2 siRNA-treated cells show enhanced migration on astrocytic monolayers, suggesting that this GEF is involved in Eph/Ephrin-mediated Schwann cell-astrocyte interactions.

Schwann cell migration is dependent on integrins. In our experiments, we examined Schwann cell migration on laminin, which has been shown previously to be dependent on the $\beta 1$ class of integrins (Milner et al., 1997), and we also have evidence that Schwann cell migration on astrocytes is integrin dependent. We therefore hypothesized that ephrin binding to Schwann cell EphA receptor might affect integrin function. There is previous evidence suggesting that Eph activation can modulate various processes such as cell adhesion, neurite outgrowth, synapse formation, and migration by modulating integrin function (Davy and Robbins, 2000; Miao et al., 2000; Deroanne et al., 2003; Bourgin et al., 2007).

When activated integrins engage with a ligand, they signal by increasing the phosphorylation of FAK (Schmitz et al., 2005; Robles and Gomez, 2006), and previous studies have shown that Eph receptor activation can reduce the phosphorylation of FAK (Miao et al., 2000; Bourgin et al., 2007). We find that this mechanism operates in Schwann cells, because we show that application of ephrinA5 reduces the phosphorylation of FAK in Schwann cells. If astrocyte-produced ephrinA5 is responsible for inhibiting Schwann cell migration by modulating integrin function, it should be possible to see a reduction in pFAK where the cell types are in contact. We saw a reduction in pFAK, but only in Schwann cells in direct contact with the astrocytes. The effects of inhibitory molecules that affect integrin activation and signaling can generally be overcome by forcing integrins into the activated state by treatment with $\mathrm{Mn}^{2+}$ (Ivins et al., 2000; Miao et al., 2000). Application of $\mathrm{Mn}^{2+}$ in our experiments overcame the inhibitory effect of clustered ephrinA5 on Schwann cell migration, providing additional evidence that the action of ephrinAs on Schwann cells affects migration through the modulation of integrin function. We further show that knockdown of VAV2 abolishes the inhibitory effect of ephrinA5 on integrin-mediated Schwann cell migration on laminin.

Our results demonstrate a sequence of events whereby ephrinAs produced by astrocytes hinder Schwann cell migration by activating their EphA receptors, signaling through VAV2, and affecting integrin function. This is not the only mechanism that affects Schwann cell-astrocyte interactions. N-cadherin is responsible for homotypic and heterotypic adhesion between the cell types, and this powerful adhesion inhibits Schwann cell migration on astrocytes and cell mixing (Wilby et al., 1999; Fairless et al., 2005). Both N-cadherin and Ephs have been shown previously to be involved in the sorting and guidance of neural crest cells from which Schwann cells are derived (Jessen and Mirsky, 2005; Kasemeier-Kulesa et al., 2006).

There is also evidence for the involvement of astrocyteproduced CSPGs in the restriction of Schwann cell migration and intermingling (Grimpe et al., 2005). At Schwann cell-astrocyte boundaries, the astrocytes hypertrophy and upregulate levels of neurocan and other CSPGs (Lakatos et al., 2000; Plant et al., 2001). FGF2 and heparan sulfate proteoglycans have been shown to be involved in this astrocytic reaction (Santos-Silva et al., 2007), but it is probable that Eph/ephrin mechanisms may also be involved because, in EphA4 knock-out animals, there is reduced glial scar formation after injury (Goldshmit et al., 2004).

In summary, we have demonstrated a role for Ephs and ephrins in the migration and intermingling of Schwann cells in relation to astrocytes. We show that this effect is mediated through VAV2 signaling and inhibition of integrin function. 


\section{References}

Adcock KH, Brown DJ, Shearer MC, Shewan D, Schachner M, Smith GM, Geller HM, Fawcett JW (2004) Axon behaviour at Schwann cell-astrocyte boundaries: manipulation of axon signalling pathways and the neural adhesion molecule L1 can enable axons to cross. Eur J Neurosci 20:1425-1435.

Andrews MR, Stelzner DJ (2007) Evaluation of olfactory ensheathing and schwann cells after implantation into a dorsal injury of adult rat spinal cord. J Neurotrauma 24:1773-1792.

Biernaskie J, Sparling JS, Liu J, Shannon CP, Plemel JR, Xie Y, Miller FD, Tetzlaff W (2007) Skin-derived precursors generate myelinating Schwann cells that promote remyelination and functional recovery after contusion spinal cord injury. J Neurosci 27:9545-9559.

Bourgin C, Murai KK, Richter M, Pasquale EB (2007) The EphA4 receptor regulates dendritic spine remodeling by affecting beta1-integrin signaling pathways. J Cell Biol 178:1295-1307.

Brockes JP, Fields KL, Raff MC (1979) Studies on cultured rat Schwann cells. I. Establishment of purified populations from cultures of peripheral nerve. Brain Res 165:105-118.

Bundesen LQ, Scheel TA, Bregman BS, Kromer LF (2003) Ephrin-B2 and EphB2 regulation of astrocyte-meningeal fibroblast interactions in response to spinal cord lesions in adult rats. J Neurosci 23:7789-7800.

Bunge MB (2008) Novel combination strategies to repair the injured mammalian spinal cord. J Spinal Cord Med 31:262-269.

Bunge MB, Pearse DD (2003) Transplantation strategies to promote repair of the injured spinal cord. J Rehabil Res Dev 40:55-62.

Casella GT, Bunge RP, Wood PM (1996) Improved method for harvesting human Schwann cells from mature peripheral nerve and expansion in vitro. Glia 17:327-338.

Cowan CW, Shao YR, Sahin M, Shamah SM, Lin MZ, Greer PL, Gao S, Griffith EC, Brugge JS, Greenberg ME (2005) Vav family GEFs link activated Ephs to endocytosis and axon guidance. Neuron 46:205-217.

Dam-Hieu P, Liu S, Choudhri T, Said G, Tadié M (2002) Regeneration of primary sensory axons into the adult rat spinal cord via a peripheral nerve graft bridging the lumbar dorsal roots to the dorsal column. J Neurosci Res 68:293-304.

Davy A, Robbins SM (2000) Ephrin-A5 modulates cell adhesion and morphology in an integrin-dependent manner. EMBO J 19:5396-5405.

Deroanne C, Vouret-Craviari V, Wang B, Pouysségur J (2003) EphrinA1 inactivates integrin-mediated vascular smooth muscle cell spreading via the Rac/PAK pathway. J Cell Sci 116:1367-1376.

Fabes J, Anderson P, Brennan C, Bolsover S (2007) Regenerationenhancing effects of EphA4 blocking peptide following corticospinal tract injury in adult rat spinal cord. Eur J Neurosci 26:2496-2505.

Fairless R, Frame MC, Barnett SC (2005) N-cadherin differentially determines Schwann cell and olfactory ensheathing cell adhesion and migration responses upon contact with astrocytes. Mol Cell Neurosci 28:253-263.

Fok-Seang J, Mathews GA, ffrench-Constant C, Trotter J, Fawcett JW (1995) Migration of oligodendrocyte precursors on astrocytes and meningeal cells. Dev Biol 171:1-15.

Fraher JP (1999) The transitional zone and CNS regeneration. J Anat 194: 161-182.

Gao PP, Yue Y, Zhang JH, Cerretti DP, Levitt P, Zhou R (1998) Regulation of thalamic neurite outgrowth by the Eph ligand ephrin-A5: implications in the development of thalamocortical projections. Proc Natl Acad Sci U S A 95:5329-5334.

Geller HM, Fawcett JW (2002) Building a bridge: engineering spinal cord repair. Exp Neurol 174:125-136.

Ghirnikar RS, Eng LF (1995) Chondroitin sulfate proteoglycan staining in astrocyte-Schwann cell co-cultures. Glia 14:145-152.

Goldshmit Y, Galea MP, Wise G, Bartlett PF, Turnley AM (2004) Axonal regeneration and lack of astrocytic gliosis in EphA4-deficient mice. J Neurosci 24:10064-10073.

Grimpe B, Pressman Y, Lupa MD, Horn KP, Bunge MB, Silver J (2005) The role of proteoglycans in Schwann cell/astrocyte interactions and in regeneration failure at PNS/CNS interfaces. Mol Cell Neurosci 28:18-29.

Guest JD, Rao A, Olson L, Bunge MB, Bunge RP (1997) The ability of human Schwann cell grafts to promote regeneration in the transected nude rat spinal cord. Exp Neurol 148:502-522.

Haramis AP, Perrakis A (2006) Selectivity and promiscuity in Eph receptors. Structure 14:169-171.
Hornstein I, Alcover A, Katzav S (2004) Vav proteins, masters of the world of cytoskeleton organization. Cell Signal 16:1-11.

$\mathrm{Hu}$ F, Strittmatter SM (2008) The N-terminal domain of Nogo-A inhibits cell adhesion and axonal outgrowth by an integrin-specific mechanism. J Neurosci 28:1262-1269.

Hunter SG, Zhuang G, Brantley-Sieders D, Swat W, Cowan CW, Chen J (2006) Essential role of Vav family guanine nucleotide exchange factors in EphA receptor-mediated angiogenesis. Mol Cell Biol 26:4830-4842.

Ivins JK, Yurchenco PD, Lander AD (2000) Regulation of neurite outgrowth by integrin activation. J Neurosci 20:6551-6560.

Jessen KR, Mirsky R (2005) The origin and development of glial cells in peripheral nerves. Nat Rev Neurosci 6:671-682.

Kasemeier-Kulesa JC, Bradley R, Pasquale EB, Lefcort F, Kulesa PM (2006) Eph/ephrins and N-cadherin coordinate to control the pattern of sympathetic ganglia. Development 133:4839-4847.

Krull CE, Lansford R, Gale NW, Collazo A, Marcelle C, Yancopoulos GD, Fraser SE, Bronner-Fraser M (1997) Interactions of Eph-related receptors and ligands confer rostrocaudal pattern to trunk neural crest migration. Curr Biol 7:571-580.

Kullander K, Croll SD, Zimmer M, Pan L, McClain J, Hughes V, Zabski S, DeChiara TM, Klein R, Yancopoulos GD, Gale NW (2001) Ephrin-B3 is the midline barrier that prevents corticospinal tract axons from recrossing, allowing for unilateral motor control. Genes Dev 15:877-888.

Lakatos A, Franklin RJ, Barnett SC (2000) Olfactory ensheathing cells and Schwann cells differ in their in vitro interactions with astrocytes. Glia 32:214-225.

Li Y, Li D, Raisman G (2005) Interaction of olfactory ensheathing cells with astrocytes may be the key to repair of tract injuries in the spinal cord: the “pathway hypothesis." J Neurocytol 34:343-351.

McCarthy KD, de Vellis J (1980) Preparation of separate astroglial and oligodendroglial cell cultures from rat cerebral tissue. J Cell Biol 85:890-902.

Mellitzer G, Xu Q, Wilkinson DG (1999) Eph receptors and ephrins restrict cell intermingling and communication. Nature 400:77-81.

Miao H, Burnett E, Kinch M, Simon E, Wang B (2000) Activation of EphA2 kinase suppresses integrin function and causes focal-adhesion-kinase dephosphorylation. Nat Cell Biol 2:62-69.

Milner R, Wilby M, Nishimura S, Boylen K, Edwards G, Fawcett J, Streuli C, Pytela R, ffrench-Constant C (1997) Division of labor of Schwann cell integrins during migration on peripheral nerve extracellular matrix ligands. Dev Biol 185:215-228.

Monschau B, Kremoser C, Ohta K, Tanaka H, Kaneko T, Yamada T, Handwerker C, Hornberger MR, Löschinger J, Pasquale EB, Siever DA, Verderame MF, Müller BK, Bonhoeffer F, Drescher U (1997) Shared and distinct functions of RAGS and ELF-1 in guiding retinal axons. EMBO J 16:1258-1267.

Morrissey TK, Kleitman N, Bunge RP (1991) Isolation and functional characterization of Schwann cells derived from adult peripheral nerve. J Neurosci 11:2433-2442.

Mould AP, Akiyama SK, Humphries MJ (1995) Regulation of integrin alpha 5 beta 1-fibronectin interactions by divalent cations. Evidence for distinct classes of binding sites for $\mathrm{Mn}^{2+}, \mathrm{Mg}^{2+}$, and $\mathrm{Ca}^{2+}$. J Biol Chem 270:26270-26277.

Pearse DD, Sanchez AR, Pereira FC, Andrade CM, Puzis R, Pressman Y, Golden K, Kitay BM, Blits B, Wood PM, Bunge MB (2007) Transplantation of Schwann cells and/or olfactory ensheathing glia into the contused spinal cord: survival, migration, axon association, and functional recovery. Glia 55:976-1000.

Plant GW, Bates ML, Bunge MB (2001) Inhibitory proteoglycan immunoreactivity is higher at the caudal than the rostral Schwann cell grafttransected spinal cord interface. Mol Cell Neurosci 17:471-487.

Richardson PM, McGuinness UM, Aguayo AJ (1982) Peripheral nerve autografts to the rat spinal cord: studies with axonal tracing methods. Brain Res 237:147-162.

Robinson V, Smith A, Flenniken AM, Wilkinson DG (1997) Roles of Eph receptors and ephrins in neural crest pathfinding. Cell Tissue Res 290:265-274.

Robles E, Gomez TM (2006) Focal adhesion kinase signaling at sites of integrin-mediated adhesion controls axon pathfinding. Nat Neurosci 9:1274-1283.

Santos-Silva A, Fairless R, Frame MC, Montague P, Smith GM, Toft A, Riddell JS, Barnett SC (2007) FGF/heparin differentially regulates 
Schwann cell and olfactory ensheathing cell interactions with astrocytes: a role in astrocytosis. J Neurosci 27:7154-7167.

Sawai H, Okada Y, Funahashi H, Matsuo Y, Takahashi H, Takeyama H, Manabe T (2005) Activation of focal adhesion kinase enhances the adhesion and invasion of pancreatic cancer cells via extracellular signal-regulated kinase-1/2 signaling pathway activation. Mol Cancer $4: 37$.

Schmitz KJ, Grabellus F, Callies R, Otterbach F, Wohlschlaeger J, Levkau B, Kimmig R, Schmid KW, Baba HA (2005) High expression of focal adhesion kinase (p125FAK) in node-negative breast cancer is related to overexpression of HER-2/neu and activated Akt kinase but does not predict outcome. Breast Cancer Res 7:R194-R203.

Silver J, Miller JH (2004) Regeneration beyond the glial scar. Nat Rev Neurosci 5:146-156.

Sims TJ, Gilmore SA (1994) Regrowth of dorsal root axons into a radiationinduced glial-deficient environment in the spinal cord. Brain Res 634:113-126.

Sims TJ, Durgun MB, Gilmore SA (1998) Schwann cell invasion of ventral spinal cord: the effect of irradiation on astrocyte barriers. J Neuropathol Exp Neurol 57:866-873.

Smith A, Robinson V, Patel K, Wilkinson DG (1997) The EphA4 and EphB1 receptor tyrosine kinases and ephrin-B2 ligand regulate targeted migration of branchial neural crest cells. Curr Biol 7:561-570.

Sobel RA (2005) Ephrin A receptors and ligands in lesions and normalappearing white matter in multiple sclerosis. Brain Pathol 15:35-45.
Tabesh H, Amoabediny G, Nik NS, Heydari M, Yosefifard M, Siadat SO, Mottaghy K (2009) The role of biodegradable engineered scaffolds seeded with Schwann cells for spinal cord regeneration. Neurochem Int 54:73-83.

Takami T, Oudega M, Bates ML, Wood PM, Kleitman N, Bunge MB (2002) Schwann cell but not olfactory ensheathing glia transplants improve hindlimb locomotor performance in the moderately contused adult rat thoracic spinal cord. J Neurosci 22:6670-6681.

Wilby MJ, Muir EM, Fok-Seang J, Gour BJ, Blaschuk OW, Fawcett JW (1999) N-Cadherin inhibits Schwann cell migration on astrocytes. Mol Cell Neurosci 14:66-84.

Winslow JW, Moran P, Valverde J, Shih A, Yuan JQ, Wong SC, Tsai SP, Goddard A, Henzel WJ, Hefti F, et al (1995) Cloning of AL-1, a ligand for an Eph-related tyrosine kinase receptor involved in axon bundle formation. Neuron 14:973-981.

Xu Q, Alldus G, Holder N, Wilkinson DG (1995) Expression of truncated Sek-1 receptor tyrosine kinase disrupts the segmental restriction of gene expression in the Xenopus and zebrafish hindbrain. Development 121:4005-4016.

Xu Q, Mellitzer G, Wilkinson DG (2000) Roles of Eph receptors and ephrins in segmental patterning. Philos Trans R Soc Lond B Biol Sci 355: 993-1002.

Yamauchi J, Chan JR, Shooter EM (2004) Neurotrophins regulate Schwann cell migration by activating divergent signaling pathways dependent on Rho GTPases. Proc Natl Acad Sci U S A 101:8774-8779. 